\title{
Sisäkorvaistutetta käyttävien lasten viittomakielen ja puhutun kielen omaksuminen
}

\author{
RITVA TAKKINEN \\ Jyväskylän yliopisto
}

Tiivistelmä. Artikkeli käsittelee suomalaisen viittomakielen ja suomen kielen kehitystä kuudella kuurolla sisäkorvaistutetta käyttävällä lapsella. Lasten kuulevat vanhemmat alkoivat opiskella ja käyttää viittomakieltä lastensa kanssa kuulovammadiagnoosin selvittyä.

Aineisto on kerätty vuosina 2005 ja 2006 kuvanauhoittamalla lapsen ja viittomakielisen aikuisen sekä lapsen ja suomenkielisen aikuisen vuorovaikutustilanteita. Lasten iät vaihtelivat 2;9 vuodesta 7;6 vuoteen tutkimuksen alussa. Taustatietoa saatiin haastattelemalla vanhempia. Kieliaineistoista analysoitiin molempien kielien sanastoa, ilmausten pituutta, nominaalien ja verbaalien taivutusta, artikulaatiota, aikuisen puheen/viittomisen ymmärtämistä ja vuorovaikutusta.

Vuoden aikana kaikkien lasten suomen kieli kehittyi. Neljällä heistä taito keskustella suomeksi, ilmausten pituus, kieliopilliset taidot ja artikulaatio paranivat huomattavasti, kahdella jonkin verran. Viittomakielen taidot kohenivat kolmella lapsella, joilla ilmausten pituus ja viittomatilaa hyväksikäyttävät kieliopilliset keinot lisääntyivät ja viittomakielinen vuorovaikutus oli sujuvampaa kuin aikaisemmin. Kolmen lapsen viittomakieli ei mainittavasti kehittynyt. Kielten kehitykseen vaikuttivat muun muassa se, että lapset saivat päivittäin enemmän syötöstä suomen kielessä ja käyttävät sitä enemmän kuin viittomakieltä.

Avainsanat: suomalainen viittomakieli; bimodaalinen kahden ensikielen omaksuminen; sisäkorvaistute 


\section{Johdanto}

Bimodaalista kaksikielisyyttä on tutkittu hyvin vähän. Bimodaalinen kaksikielisyys tarkoittaa sitä, että henkilön omaksumat tai hallitsemat kaksi kieltä ovat erimodaalisia, ts. toinen on auditiivis-oraalinen puhuttu kieli ja toinen on visuo-spatiaalinen viitottu kieli. Bimodaalisen kaksikielisyyden onnistuminen epäilyttää monia kuulonhuollon edustajia, jotka kuitenkin ohjaavat kuurojen ja vaikeasti huonokuuloisten lasten kielivalintoja (Kotti 2002; Kushalnagar ym. 2010; Padden 2008). Taustalla voi olla pelko siitä, että puhuttu kieli ei kehitykään hyvin, sekä vähättelevä asenne viittomakieltä kohtaan. Viittomakieltä ei pidetä oikeana tai arvostettavana kielenä (prestiisikielenä) vaan vain hätävarana silloin, kun puhuttu kieli ei syystä tai toisesta kehity. Tapio ja Takkinen (2012) ovat vanhempia haastatellen selvittäneet, miten esimerkiksi kuulokeskuksissa, päiväkodissa ja muussa lähiympäristössä suhtaudutaan sisäkorvaistutetta käyttävien lasten viittomakielen käyttöön. Tuloksista käy ilmi, että kuulonhuollon edustajat ajattelevat edelleenkin viittomakielen ehkäisevän tai hidastavan puhutun kielen omaksumista. Bimodaalisen kaksikielisyyden ja ennen kaikkea sen kehittymisen tieteellinen tutkimus on siis tärkeää, jotta perheille annettaisiin monipuolista tietoa kielenkehityksestä.

1980- ja 1990-luvuilla lähes kaikki kuurojen lasten kuulevat vanhemmat ryhtyivät opiskelemaan viittomakieltä ja käyttämään sitä lastensa kanssa kommunikoidessaan. Niinpä lapset alkoivat omaksua viittomakieltä jo varhain. Huolimatta siitä, että kuulevat vanhemmat käyttivät viittomakieltä vieraana kielenä ja heidän taitonsa siinä vaihtelivat paljon, lapset pääsivät ensikieleen kiinni suhteellisen hyvin, ellei heillä ollut kielenkehityksen erityisvaikeutta. Takkisen (2003) monitapaustutkimuksessa seurattiin sekä äidinkielisessä että kuulevassa viittovassa ympäristössä elävien kuurojen lasten viittomakielen kehitystä. Puolentoista vuoden iässä molempien ryhmien lapset olivat samassa osoituksen ja viittoman tai kahden viittoman yhdistelmän vaiheessa. Kun kieliopillinen kehitys pääsi alkuun äidinkielisessä ympäristössä elävillä 


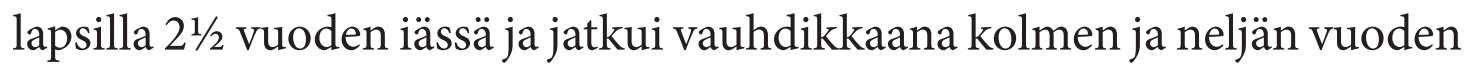
iässä, ei-äidinkielisessä ympäristössä elävien lasten kieliopillinen kehitys kulki karkeasti arvioiden vuoden verran jäljessä. Kuitenkin myös he pystyivät viittomakielellä keskustelemaan asioistaan, esittämään tarpeitaan ja kommentoimaan tapahtumia, vaikka heidän vuorovaikutustaitonsa eivät olleetkaan niin sujuvat kuin äidinkielisessä ympäristössä elävillä lapsilla. Viiden ja kuuden ikävuoden välillä ei-äidinkielisessä ympäristössä elävät lapset tavoittivat äidinkielisessä ympäristössä eläviä lapsia kieliopillisessa kehityksessä, joten kouluun mennessään heillä oli suhteellisen hyvät valmiudet viittomakielessä. Suomalaisen viittomakielen kehityksen mittaamiseen ei ole testejä, vaan arviot perustuvat äidinkielisessä ympäristössä elävien lasten kehitykseen, muista viittomakielistä saatuihin tuloksiin ja puhuttujen kielten vastaaviin tuloksiin vertaamiseen. Lasten hyvään kielelliseen kehitykseen ovat vaikuttaneet vanhempien kielitaidon parantuminen viittomakielen opiskelun ja käytön myötä sekä lasten laajemmat kontaktit viittomakielisiin aikuisiin ja lapsiin.

1990-luvun loppupuolella uudentyyppisiä kuulon apuvälineitä, sisäkorvaistutteita ${ }^{1}$, alettiin Suomessa leikata aikuisten lisäksi myös lapsille. Ajateltiin lasten oppivan kuulemaan niin hyvin, ettei viittomakieltä enää tarvittaisikaan. Niinpä kuulokeskusten ohje oli käyttää ainoastaan tukiviittomia ja mahdollisesti vähitellen viitottua puhetta - ei viittomakieltä - lasten kanssa (Ahti 2000; Kotti 2002), koska viittomakielen ajateltiin ehkäisevän tai hidastavan puhutun kielen kehitystä. Tälle väitteelle ei ole kuitenkaan tutkimuspohjaa, mutta tutkimukset osoittavat, että lapset voivat omaksua kahta tai useampaakin kieltä, kun heillä on mahdollisuus saada syötöstä näissä kielissä ja käyttää niitä monipuolisesti. Kehityksen alkuvaiheessa kielten kehittyminen voi kuitenkin olla hiukan hitaampaa kuin yksikielisillä lapsilla. (Esim. Baker 2001; Hassinen

\footnotetext{
1 Sisäkorvaistute on kuulon apuväline, jossa on kirurgisesti kalloluuhun asennettavat sisäiset osat ja ulkoiset osat, jotka vievät äänisignaalin järjestelmän sisäosiin. Siellä sähkösignaalit stimuloivat kuulohermon säikeitä ja nämä johtavat hermoimpulssit aivojen kuuloalueelle. Ks. http://www.kuuloliitto.fi/fin/kuulo/sisakorvaistute/ rakennel (9.8.2013).
} 
2005; De Houwer 2009; Yip \& Matthews 2007; Bialystok 2010). Kuurojen ja vaikeasti kuulovammaisten lasten kaksikieliseksi kehittyminen tietenkin edellyttää, että heidän kuulevat vanhempansa ohjataan opiskelemaan ja käyttämään viittomakieltä, kuten 1980- ja 1990-luvulla tehtiin Suomessa ja muissa Pohjoismaissa. Nykyisin vain osa vanhemmista käyttää sekä viittomakieltä (tai viitottua suomea) että puhuttua suomen kieltä. Perheet ovat saaneet kotikuntiensa kustantamana perheopetusta ja/tai osallistuneet Kuurojen Palvelusäätiön Juniori-ohjelmaan², joka tarjoaa perheille viittomakielen opetusta ja tutustumismahdollisuuksia viittomakieliseen kulttuuriin sekä lapsille "kielikylpyä" viittomakielessä.

\section{Kaksikieliseksi kehittyminen}

Kaksi kieltä kehittyy toisiinsa nähden sekä itsenäisesti että toisiinsa vaikuttaen. Tutkijat ovat havainneet, että lapset erottavat omaksumansa kielet jo varhain toisistaan (Petitto ym. 2001; Deuchar \& Quay 1999; Meisel 2004). Toisaalta kielet vaikuttavat toisiinsa kieliopin kehittyessä, mikä näkyy joidenkin kieliopillisten piirteiden transferina kielestä toiseen tai esimerkiksi jonkin kieliopillisen piirteen omaksumisen helppoutena toisessa kielessä (mm. Genesee \& Nicoladis 2006; Petitto ym. 2001).

Kaksikielisten molemmat kielet ovat erittäin harvoin yhtä vahvoja ja käyttöalueiltaan identtisiä. Usein toinen kieli dominoi, eli sitä osataan paremmin ja käytetään enemmän. Kielten dominanssi voi elämän mittaan myös vaihtua, jos toista kieltä syystä tai toisesta aletaan käyttää enemmän yhä useammissa tilanteissa (esim. Baker 2006; De Houwer 2009; Grosjean 2010). Kaksikieliset omaksuvat ja käyttävät tavallisesti kieliään eri tarkoituksiin, eri elämänalueilla ja eri ihmisten kanssa (Grosjean 2010; Pietikäinen, Dufva \& Mäntylä 2010). Grosjeanin (2010) mukaan kielten käytössä vallitsee täydennysperiaate. Kun kaksi- tai monikielisyyttä tarkastellaan kielellisinä resursseina (vrt. Heller 2007; Mäntylä, Pietikäinen \& Dufva 2009) eikä pelkästään lingvistisinä rakenteina ja niiden hallitsemisena, suhtautuminen eri kielten käyttöön ja

\footnotetext{
2 http://www.kuurojenpalvelusaatio.fi/fin/apua arkeen/juniori-ohjelma/ (9.8.2013).
} 
yksilöllisiin kielellisiin repertuaareihin muuttuu positiivisemmaksi ja sallivammaksi.

Kahden kielen omaksuminen voi olla samanaikaista eli simultaania tai peräkkäistä eli sekventiaalista. Simultaaniin kahden kielen kehitykseen on monia reittejä, ei ainoastaan yksi kieli-yksi vanhempi -käytäntö (esim. Baker 2001; Grosjean 2010). Toinen tapa on esimerkiksi se, että kotona käytetään yhtä kieltä ja ympäristössä toista. Vanhemmat voivat myös käyttää vaihdellen kumpaakin kieltä lapsen kanssa. Toisen kielen käyttö voidaan myös aloittaa myöhemmin, kun ensimmäisen kielen taito on suhteellisen vankka, jolloin kahden kielen omaksuminen on sekventiaalista. Perheiden ja lasten elämäntilanne sekä ympäröivä yhteiskunta vaikuttavat suuresti siihen, minkälaisia kielivalintoja perheessä tehdään.

Koodinvaihto eli toisen kielen sanojen tai fraasien käyttö ilmaisussa toista kieltä puhuttaessa on luonnollinen ilmiö, kun se noudattaa tiettyjä sääntöjä. Koodia vaihdetaan yleensä toisen kaksikielisen henkilön kanssa keskusteltaessa, jolloin keskustelijat toimivat kaksikielisessä moodissa eli molemmat kielet ovat aktiivisia tilanteessa (Grosjean 2010). Koodinvaihtoon vaikuttavat hyvin monet tekijät, esimerkiksi puuttuvan sanan/ viittoman tilalla käytetään toisen kielen sanaa tai toisen kielen sana/viittoma ilmaisee puheena olevan asian nasevammin. Myös pragmaattiset tekijät, kuten asian korostaminen, toisen puheen lainaaminen tai identiteetin osoittaminen, voivat saada aikaan koodinvaihtoa. Kahden kielen käyttäjän on helpompi ymmärtää ihmisten välistä kommunikaatiota monipuolisesti ja olla siinä joustavampi kuin yhden kielen käyttöön tottuneen. (Baker 2006; De Houwer 2009; Grosjean 2010). Kieltä omaksuvilla lapsillakin esiintyy koodinvaihtoa, mutta se ei heilläkään merkitse puutteellista kielitaitoa tai ennakoi heikkoa kielten hallintaa vaan kuuluu luonnollisena osana kehitykseen.

Lapsen elinympäristössä olevien ihmisten, perheen, yhteiskunnan ja koulujärjestelmän suhtautuminen kaksikielisyyteen voi olla sitä rikastuttavaa, ylläpitävää tai voi johtaa toisen kielen vahvistumiseen toisen kustannuksella. Kun molempien kielten kehittymistä ja käyttöä tuetaan, kielillä on mahdollisuus kehittyä toimiviksi kielellisiksi resursseiksi. 
Kaksi- tai monikielinen lapsi voi myös menettää yhden tai useamman kielistään. Ilmiötä kutsutaan kielen attritioksi. Kun tietyn kielen käyttö vähenee huomattavasti tai lakkaa, alkaa kielen unohtaminen, joka kestää vuosia. (Grosjean 2010.)

Kahden puhutun kielen omaksumista on tutkittu varsin paljon eri kieliyhdistelmien näkökulmasta, mutta visuaalista ja auditiivista kanavaa käyttävien kielten varhaista omaksumista on tutkittu vasta hyvin vähän. Siksi bimodaalista asetelmaa käyttävä tutkimus tuo uuden näkökulman kahden ensikielen omaksumiseen. Tässä artikkelissa tarkastellaan sitä, 1) kuinka suomi ja suomalainen viittomakieli kehittyvät vuoden aikana sisäkorvaistutetta käyttävillä lapsilla ja 2) minkälainen on heidän kieliympäristönsä ja kielten käyttö arjessa. Koska lapset ovat eri-ikäisiä (2;9-7;6 vuotta) ja he ovat käyttäneet sisäkorvaistutetta eripituisen ajan (0;6-5;3 vuotta), tuloksia ei voi arvioida yksityiskohtaisesti ryhmätasolla (taulukko 1). Pikemminkin kunkin lapsen kehitystä heijastetaan hänen omaan edelliseen aineistoonsa ja arvioidaan sekä suomenkielisten että viittomakielisten lasten kielenkehityksen valossa (Hassinen 2005; Takkinen 2003; Chen Pichler 2012). Bimodaalisesta kahden ensikielen omaksumisesta ei Suomessa ole aikaisempaa tutkimusta, joten tällä tutkimuksella pyritään saamaan yleistä kuvaa auditiivisen ja visuaalisen kielen rinnakkaisesta kehityksestä.

\section{Aineisto ja menetelmät}

\subsection{Aineisto ja informantit}

Tutkimus on monitapaustutkimus, jossa seurataan kuutta Juniori-ohjelmaan osallistuvaa sisäkorvaistutetta käyttävää lasta, jotka ovat ensin omaksuneet viittomakieltä ja sitten sisäkorvaistutteen saatuaan vähitellen myös puhuttua suomen kieltä. Nämä lapset valikoituivat tutkittaviksi, koska heidän perheissään käytettiin molempia kieliä eikä lapsilla ollut todettu mitään kielenkehitystä vaikeuttavaa tekijää. Tutkimus on pitkittäistutkimus, jossa lasten molempien kielien kehitystä ja käyttöä seurataan useamman vuoden ajan. Aineistoa kerätään kerran vuodessa. Tässä 
artikkelissa analysoitu aineisto on kerätty vuosina 2005 ja 2006 (taulukko 1). Suomenkielinen aineisto on kuvanauhoitettu tilanteissa, joissa lapsi on vuorovaikutuksessa suomenkielisen aikuisen kanssa. Viittomakielinen aineisto on vastaavasti kuvattu viittomakielisen aikuisen kanssa. Vuorovaikutustilanteissa lapsi on katsellut kuvakirjaa (ensimmäisellä kerralla "Pupu Tupunan pulma" ja toisella kerralla "Pupu Tupunan loruaapinen") ja keskustellut siitä aikuisen kanssa, kertonut kuvista ja keskustellut harrastuksista tai kesälomasta ja kesänvietosta. Viittomakielisen samoin kuin suomenkielisen aineiston pituus lasta kohden oli 2005 7-10 minuuttia ja vuonna 2006 12-15 minuuttia. Aineisto on dialogista ja narratiivista.

TAULUкKо 1. Lasten ikä kuulovamman diagnosointiaikaan, perheen viittomakielen opetuksen alkaessa, leikattaessa sisäkorvaistute sekä 1. ja 2. aineiston keruun aikaan

\begin{tabular}{|l|c|c|c|c|c|}
\hline Lapset & $\begin{array}{c}\text { Diagnosointi- } \\
\text { ikä }\end{array}$ & $\begin{array}{c}\text { Viittoma- } \\
\text { kielen } \\
\text { käytön } \\
\text { aloitus }\end{array}$ & $\begin{array}{c}\text { Implantointi- } \\
\text { ikä }\end{array}$ & $\begin{array}{c}\mathbf{1 .} \\
\text { aineiston } \\
\text { keruu }\end{array}$ & $\begin{array}{c}\mathbf{2 .} \\
\text { aineiston } \\
\text { keruu }\end{array}$ \\
\hline 1 Kalle & $2 ; 10$ & $2 ; 10$ & $7 ; 0$ & $7 ; 6$ & $8 ; 6$ \\
\hline 2 Ville & $3 ; 0$ & $3 ; 0$ & $4 ; 10$ & $7 ; 6$ & $8 ; 6$ \\
\hline 3 Jussi & $\begin{array}{c}\text { syntymässä } \\
(0 ; 6)\end{array}$ & syntymästä & $1 ; 6$ & $5 ; 9$ & $6 ; 9$ \\
\hline 4 Maija & $2 ; 5$ & $2 ; 5$ & $2 ; 10$ & $4 ; 6$ & $5 ; 6$ \\
\hline 5 Matti & $1 ; 0$ & $1 ; 0$ & $2 ; 2$ & $3 ; 9$ & $4 ; 9$ \\
\hline 6 Liisa & $0 ; 4$ & $0 ; 6$ & $1 ; 6$ & $2 ; 9$ & $3 ; 9$ \\
\hline
\end{tabular}

* Taulukossa ja tekstissä lapsista ei käytetä heidän oikeita nimiään.

Tutkimusaineistoon kuuluvat lapsilta kerätyn kielimateriaalin lisäksi myös tutkimuksen alussa tehdyt vanhempien haastattelut. Niissä on selvitetty vanhempien ajatuksia kielivalinnoista, saadusta kielenkehityksen ohjauksesta ja kuulolaitteisiin liittyvistä asioista sekä lapsen saamasta kuulon ja kielen kuntoutuksesta. Seuraavana vuonna vanhempien arviota lapsensa kielten kehitysvaiheista ja käytöstä on kysytty 
kyselylomakkeella. Vanhempien haastattelu- ja kyselyaineisto ovat toimineet osittain kieliympäristöön liittyvänä taustatietona, osittain tukemassa kielenkehityksen arviointia varsinaisen kieliaineiston pohjalta. Lisäksi Juniori-ohjelman kurssilla lasten kanssa toimineita lastenohjaajia on pyydetty kuvaamaan kunkin lapsen kommunikointia kurssin aikana eri toiminnoissa, jotta viittomakielen käytöstä saataisiin monipuolisempi kuva. Ohjaajat arvioivat, kuinka lapsi ymmärtää ja käyttää viittomakieltä aikuisten ja lasten kanssa.

\subsection{Kielenkehityksen arviointi kerätyn aineiston pohjalta}

Kummankin kielen aineistosta tehtiin havaintoja lapsen käyttämän kielen kehityksestä sekä rakennepiirteiden esiintymisestä yhden vuoden aikana (taulukko 2). Kielten ymmärtämistä arvioitiin havainnoimalla aikuisen ja lapsen välistä vuorovaikutusta: ymmärsikö lapsi normaalivauhtista viittomista tai puhumista, tuliko kommunikaatioon katkoksia sekä pitikö aikuisen toistaa ja esittää asiansa hitaasti ja erityisen selkeästi. Myös tottumusta viitottuun tai puhuttuun kommunikaatioon arvioitiin tarkkailemalla esimerkiksi katsekontaktia viittomakielisen keskustelun aikana, puheenvuoron vaihtelua ja keskustelualoitteiden tekemistä kummassakin kielessä. Arviointi oli laadullista.

Suomalaisen viittomakielen rakennetta on yksityiskohtaisesti tutkittu verraten vähän. Syntaktisen tasolla on tutkittu vain peruslauseita ja niiden sanajärjestystä (Jantunen 2008; 2009) sekä informaatiorakennetta (teema-reema-rakennetta) pintapuolisesti (Rissanen 1985; 2000). Jantunen (2008) on havainnut, että suomalaisen viittomakielen sanajärjestys on transitiivilauseissa usein SVO tai SOV. Sanajärjestykseen vaikuttaa kuitenkin se, onko verbi tilaan sijoitettava tai tilassa liikkuva vai ei (Takkinen 2008; 2010; Haapanen \& Wainio 2010). Kompleksisempien lauseiden rakennetta ei ole tutkittu, joten analyysissa tutkijan on turvauduttava omaan ja kielenoppaiden kielitaitoon sekä kieli-intuitioon. Toisaalta lasten taitojen arviointi perustuu myös viittomakielisten lasten kehitykseen (Takkinen 2003; ks. liite 1). 
TAULUKKо 2. Suomalaisesta viittomakielestä ja suomen kielestä arvioidut kehitys- ja rakennepiirteet

\begin{tabular}{|l|l|}
\hline \multicolumn{1}{|c|}{ Suomalainen viittomakieli } & \multicolumn{1}{c|}{ Suomen kieli } \\
\hline $\begin{array}{l}\text { viittomisto: vakiintuneiden viittomien } \\
\text { ja vakiintumattomien kuvailevien } \\
\text { viittomien käyttö }\end{array}$ & sanasto \\
\hline $\begin{array}{l}\text { ilmausten pituus ja rakenne (miten } \\
\text { pitkiä ja syntaktisesti komplekseja } \\
\text { ilmauksia lapsi tuottaa) }\end{array}$ & $\begin{array}{l}\text { ilmausten pituus ja } \\
\text { monipuolisuus (päälauseiden ja } \\
\text { sivulauseiden käyttö) }\end{array}$ \\
\hline $\begin{array}{l}\text { nominaalien ja verbaalien morfologinen } \\
\text { modifiointi (taivutus), } \\
\text { nonmanuaaliset morfologiset ja } \\
\text { syntaktiset keinot }\end{array}$ & $\begin{array}{l}\text { nominien sijataivutus sekä } \\
\text { verbien taivutus (persoona-, luku- } \\
\text { ja aikamuoto) ja verbirakenteet }\end{array}$ \\
\hline $\begin{array}{l}\text { viittoma-artikulaatio, perusparametrien, } \\
\text { kaksikätisten viittomien tuottaminen ja } \\
\text { yleinen viittomisen selkeys }\end{array}$ & artikulaatio \\
\hline $\begin{array}{l}\text { kuinka lapsi ymmärtää aikuisen } \\
\text { viittomista }\end{array}$ & $\begin{array}{l}\text { kuinka lapsi ymmärtää aikuisen } \\
\text { puhetta }\end{array}$ \\
\hline $\begin{array}{l}\text { vuorovaikutustaidot } \\
\text { vuorovaikutustaidot }\end{array}$ \\
\hline
\end{tabular}

Vuorovaikutuksesta arvioitiin viittomakielessä sitä, kuinka lapsi oli katsekontaktissa keskustelukumppaninsa kanssa ja kuinka hän seurasi toisaalta kirjaa tai kuvia ja toisaalta keskustelukumppaniaan. Molemmissa kielissä arvion kohteena oli lapsen aktiivisuus vuorovaikutuksessa ja se, kuinka hyvin hän teki itsensä ymmärretyksi tilanteessa. Suomen kielen arviointiin on olemassa mittareita, mutta tässä tutkimuksessa analysoidaan molempia kieliä samalla tavalla tarkastellen lapsen tuottamaa ja annotoitua kieliainesta ja analysoiden siitä taulukossa 2 kuvattuja kielellisiä ilmiöitä.

Viittomakielinen aineisto on annotoitu ELAN-ohjelmalla ${ }^{3}$. Kuvassa 1 näkyy videokuva, jonka alla on annotaatioalue. Siihen voi luoda rivejä

3 ELAN (EUDICO Linguistic Annotator) on multimedia-annotaatiotyökalu, joka on kehitetty Max Planck -instituutissa (Max Planck Institute for Psycholinguistics). http://www.lat-mpi.eu/tools/elan/ (9.8.2013). 
sen mukaan, millaista tietoa aineistosta haluaa transkriboida. Viittomakielestä on annotoitu omille riveilleen manuaaliset viittomat, joihin on liitetty tieto tilankäytöstä, huulio, poskien, silmien, silmäkulmien ja pään liikkeet. Lisäksi kommenttiriville on voinut lisätä muuta informaatiota. Viittomakielinen henkilö on tehnyt perusannotaation, jota tutkija on täydentänyt ja analysoinut.

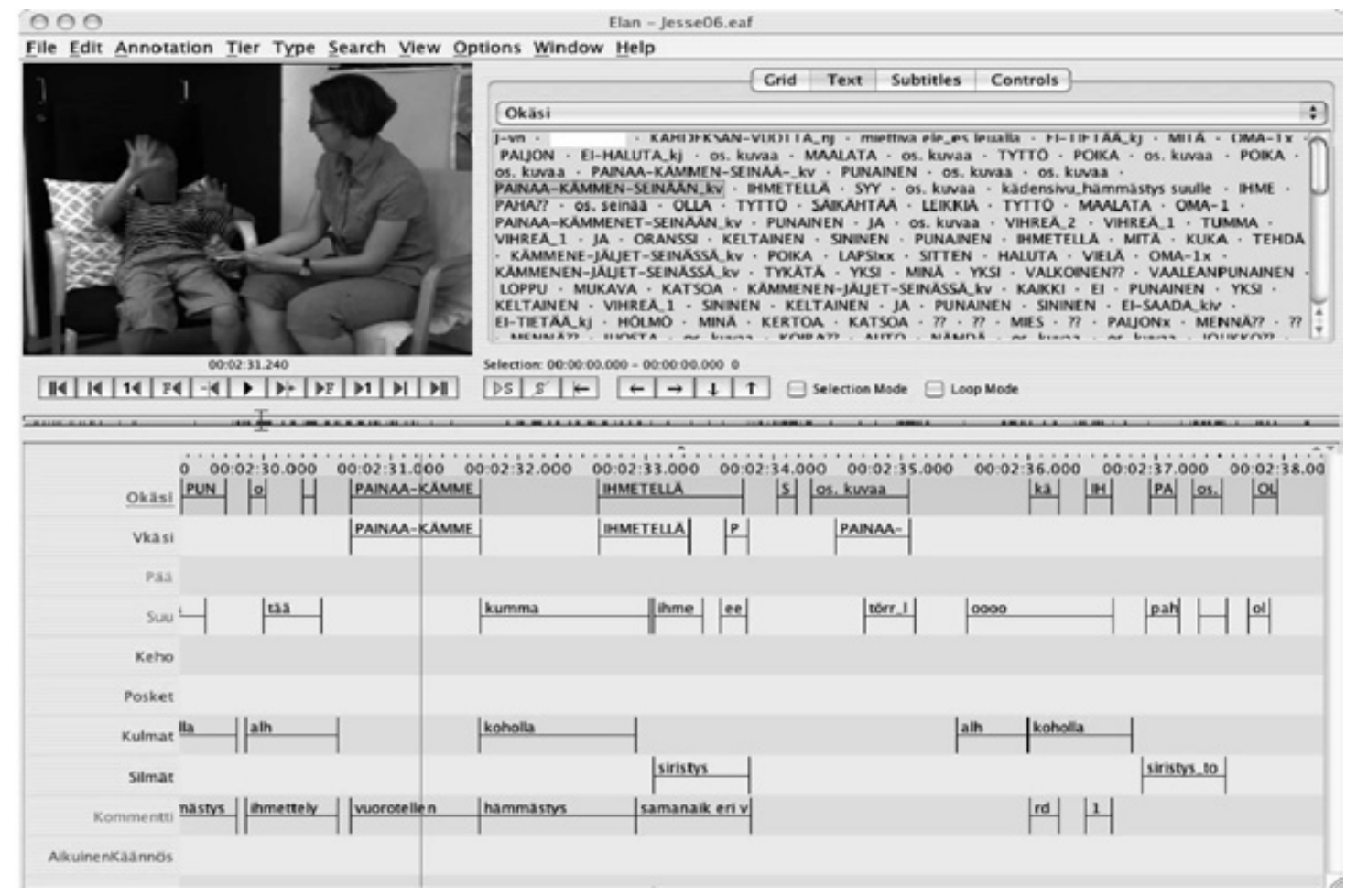

KuvA 1. ELAN-ohjelman ruutunäkymä

Suomenkielinen aineisto on annotoitu Transana-ohjelmalla ${ }^{4}$. Kuvassa 2 on esitetty ohjelman ruutunäkymä. Siinä ylinnä on puheen spektrikuva ja vieressä videokuva. Annotaatioalueeseen kirjoitetaan kukin puheenvuoro erikseen allekkain.

\footnotetext{
4 Transana on digitaalisen videon tai äänitteen analysointiohjelma, joka on kehitetty Wisconsin-Madisonin yliopistossa (Wisconsin Center for Education Research) http://www.transana.org/ (9.8.2013).
} 


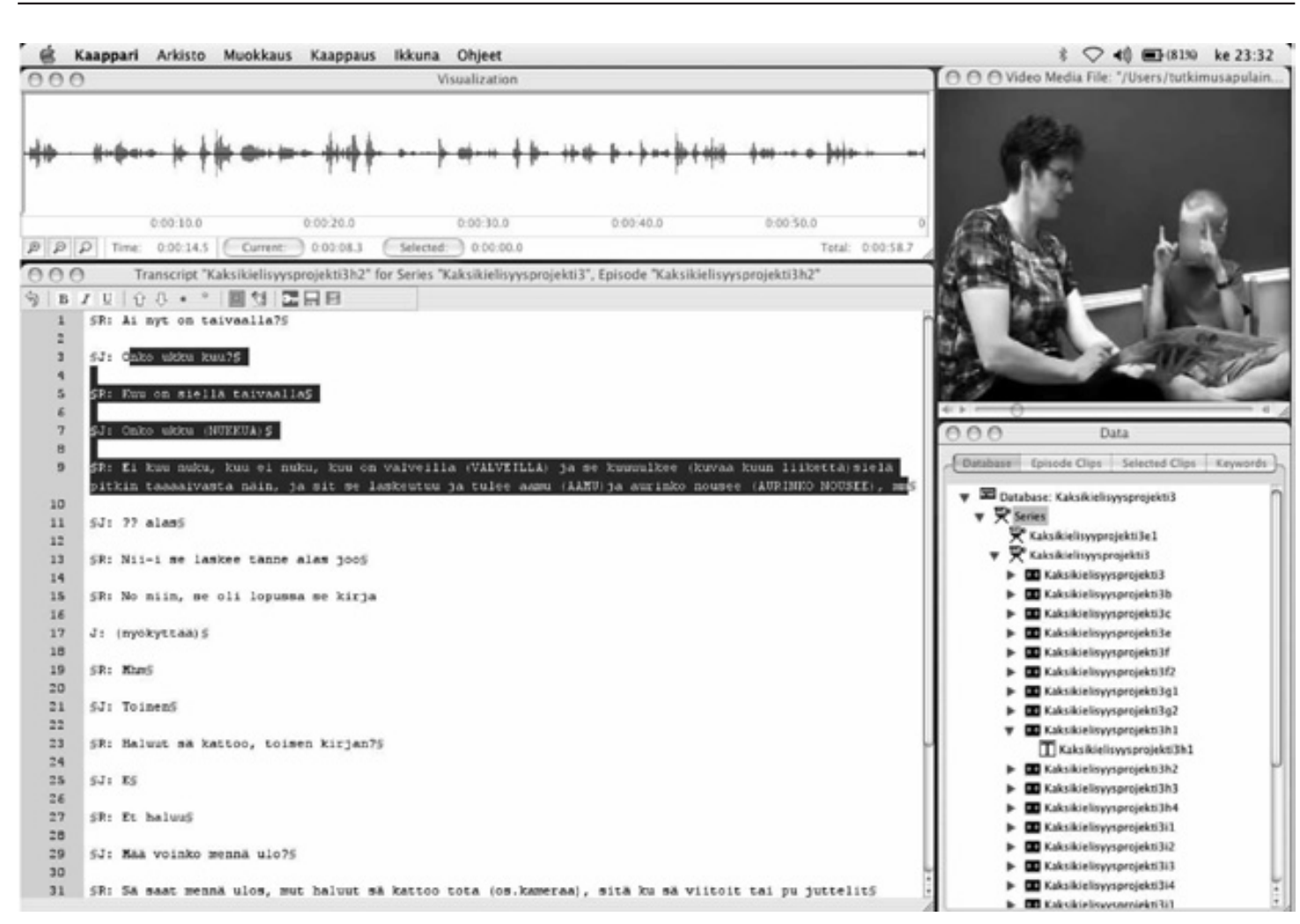

KuvA 2. Transana-ohjelman ruutunäkymä

Sekä suomen- että viittomakieliseen litteraattiin liittyy siihen ajastettu videokuva. Kielen kehitystason arviointi perustuu analyysiin, joka on tehty videokuvasta annotoidun aineiston pohjalta. Aineistosta on luokiteltu artikulaation piirteitä, kieliopillisia piirteitä sekä vuorovaikutuksen piirteitä ja tarkasteltu vuoden aikaista kehitystä. Käytän lasten tuotoksista termiä ilmaus (vrt. lausuma, Hakulinen 1997), koska se sopii paremmin puheen ja viittomakielen tarkasteluyksiköksi kuin lause tai virke, joka on paremmin määriteltävissä kirjoitetussa kielessä.

\section{Tulokset}

Koska lapset ovat keskenään eri-ikäisiä, he ovat käyttäneet sisäkorvaistutetta eripituisen ajan ja heitä on vain kuusi, he eivät muodosta mitään yhtenäistä ryhmää. Antaakseni yleiskuvan heidän yksilöllisestä kielellisestä kehityksestään olen valinnut tähän artikkeliin yksityiskohtaiseen tarkasteluun kaksi lasta: joukon vanhimman ja nuorimman, Villen ja 
Maijan, joiden kielten kehitys on erilainen. Lisäksi kuvaan muiden neljän lapsen kehitystä tiivistetymmin. Viittomakieltä käsitellään ensin, koska se on jokaiselle lapselle kieli, jota hän on omaksunut ensimmäisenä.

\subsection{Ville: 7;6 ja 8;6}

Ville diagnosoitiin kuuroksi kolmen vuoden iässä (taulukko 1). Hänen vanhempansa alkoivat opiskella viittomakieltä ja käyttää sitä lapsensa kanssa välittömästi kuultuaan Villen kuuroudesta. Ville sai sisäkorvaistutteen 4;10 iässä. Ensimmäisen aineiston keruun aikana hän oli 7;6 ja toisen $8 ; 6$.

Ville viittoi 7 1/2-vuotiaana verrattain paljon. Siihen mennessä hän oli omaksunut viittomakieltä $4 \frac{1}{2} 2$ vuotta. Hänen moniviittomaisissa ilmauksissaan (1-4) oli sekä vakiintuneita viittomia että vakiintumattomia kuvailevia viittomia (4). Viittomakielen kieliopillisista keinoista hän käytti esimerkiksi osoituksia tilaan ja verbiviittoman suuntaamista tilassa $(1,2,4)$, mutta tilan käyttö kieliopillisten suhteiden ilmaisuun ei ollut vielä systemaattista ${ }^{5}$. Käsimuodoissa oli löysyyttä (sormet eivät olleet tiukasti yhdessä tai ne olivat vähän koukistuneita suoristumisen sijaan) ja liikkeissä hiukan koordinoimattomuutta, mutta viittomaartikulaatio oli jokseenkin ymmärrettävää. (Viittoma-artikulaatiosta tarkemmin Takkinen 2002.) Ville ymmärsi rauhallista viittomista.

(1) os-3 KULTA TUKKA TYTTÖ os-3 NUKKUA os-3 PIENI KARHU NUKKUA os-3 'Se kultakutri tyttö nukkuu siinä missä pieni karhu nukkuu'

(2) NUKKUA HERÄTÄ SÄIKÄHTÄÄ-kuvailu JUOSTA-KOVAA KÄVELLÄ-1-6 '[Kultakutri] nukkuu [sitten] herää ja säikähtää ja juoksee kovaa pois'

\footnotetext{
$5 \quad$ Yksi viittomakielten kielioppiin liittyvä keskeinen piirre on tilan käyttö spatiaalisten ja kieliopillisten suhteiden ilmaisuissa. Se voi tapahtua joko viittomalla viittoma tietyssä paikassa viittomatilaa, suuntaamalla verbiviittoma tilassa tai osoittamalla tilaa tietyn entiteetin sijoittamiseksi siihen ja uudelleen viittaamalla siihen. (Ks. esim. Liddell 2003; Jantunen 2010; Takkinen 2008; 2010; Haapanen \& Wainio 2010.)
} 
(3) HEI MINÄ TEHDÄ näyttää-ilmeellä-(tämännäköinen) HEI MINÄ näyttää-ilmeellä-(tämännäköinen) (hei, minulla oli tällainen ilme)... TULLA-MIELEEN näyttää-ilmeellä-(tämännäköinen) HÖLMÖ 'Tuli mieleen ottaa tällainen hölmönnäköinen ilme’

(4) KARHU KOLME KARHU ... KÄVELLÄ-3-4-kv

Suomen kielellä Villen ilmaukset olivat melko lyhyitä, kahden kolmen sanan mittaisia (5-7). Nominien sijataivutus ja verbien taivutus olivat vasta kehittymässä (5-9). Pitemmät sanat olivat usein redusoituneet kaksitavuiseksi, konsonanttiyhtymissä oli vaikeuksia (pokkana = porkkana; mitti $=$ miksi). Lisäksi /r/ ääntyi uvulaarisena tai /l/-äänteenä ja /s/ ääntyi joskus $/ t /$-äänteenä (juuttoo $=$ juustoa). Konsonantit saattoivat korvautua toisilla tai jäädä pois kokonaan (puuahaine = muurahainen; penottaa = pelottaa + kädet suun edessä). Ville tarvitsi ajoittain viittomakielen tukea ymmärtääkseen puhetta ja viittoi itsekin silloin tällöin puheen kanssa. Hän osasi myös käyttää viittomakieltä hyväkseen, kun huomasi, ettei keskustelukumppani ymmärtänyt hänen puhettaan. Esimerkki siitä on ilmauksen (10) toistaminen viittomien kanssa samanaikaisesti (11).

(5) se on kuuma; tää menee rikki

(6) ottaa jääkaappi 'ottaa jääkaapista'

(7) te otti kovaa vauhti; mee koloo 'menee koloon'; se näkee samanlaine

(8) [Mihin se juoksee?] vetee

(9) O tää maja? 'Onko tämä maja?'

(10) Onko ukku kuu? 'Onko kuu nukkumassa?'

(11) Onko ukku kuu NUKKUA KUU

8 1/2 vuoden iässä, 5 1/2 vuotta viitottuaan, Villen vuorovaikutus kuuron aikuisen kanssa oli sujuvaa ja innokasta. Hän viittoi paljon ja pitkiä ilmauksia, joissa esiintyi viittomatilaa hyväksi käyttävien lisäksi myös ei-manuaalisia kieliopillisia keinoja ${ }^{6}(12-14)$. Viittomatilaa hän käytti

\footnotetext{
6 Ei-manuaalisia kieliopillisia keinoja ovat mm. silmäkulmien liikkeet, jotka liittyvät lausetyyppeihin, suun seudun liikkeet, jotka ovat morfologisia keinoja, sekä pään ja vartalon syntaksiin liittyvät liikkeet (esim. Rainò 2001; Pfau \& Quer 2010).
} 
muun muassa kuvailevien verbien ${ }^{7}$ yhteydessä (14). Ville oli aloitteellinen keskustelussa ja kyseli kuvista sekä kommentoi niitä. Hän myös ymmärsi hyvin aikuisen normaalivauhtista viittomista. Viittoma-artikulaatiossa käsimuodoissa oli edelleen löysyyttä ja liikkeissä hivenen koordinoimattomuutta.

(12) os-kuva MAALATA os-kuva TYTTÖ POIKA os-kuva SEINÄ PAINA-KÄMMENET-SEINÄÄN-kv ... PUNAINEN os-kuva POIKA PAINAA-KÄMMENET-kv SEINÄ / IHMETELLÄ PAINAA-KÄSISEINÄÄN MIKSI os-kuva ele-käsi-suun-eteen IHMETELLÄ MITÄ os-seinä OLLA 'Tuossa maalataan, tuossa tyttö ja poika painavat kämmeniä seinään... se on punainen, poika hämmästyy seinää ja ihmettelee, miksi ja mitä seinässä on'

(13) ... IHMETELLÄ MITÄ KUKA TEHDÄ PAINAA-KÄMMENET-SEINÄÄN-kv 'joku ihmettelee, kuka on tehnyt tällaista painellut (väri) kämmeniä seinään?'

(14) KAKSI-KÄVELLÄ-RINNAKKAIN-1-4-kv; KULKUNEUVO-AJAAALAMÄKEÄ-PERUUTTAA-YLÄMÄKEÄ-kv

Käytettyään sisäkorvaistutetta noin $3 \frac{1}{2}$ vuotta Ville puhui jo pitkiä ilmauksia (15-16). Verbikonstruktiot ja nominien sijataivutus olivat monipuolistuneet vuoden aikana (17-18), joskin puutteita edelleen esiintyi (19-20). Ääntäminen oli suhteellisen hyvää, vain $/ r /$ - ja $/ s /$-äänteiden ääntämisessä oli variaatioita: konsonanttiyhtymissä $/ r /$ saattoi jäädä pois ja sanan alussa $/ s /$ ääntyi $/ t /$ :nä (peehone = perhonen; tos $y k s$ kissa toittaa $=$ soittaa). Jos Ville puhui nopeasti, puhetta oli vaikeampi ymmärtää. Hän itse ymmärsi hyvin puhetta, mutta tarvitsi siihen visuaalista tukea.

(15) No te pupu menee tinne, ai no vaikka tinne maantielle

(16) no tyttö, joka voi nukkuu piironkilla

(17) ne on menossa kotiin; lehmä on juossu; se on kaatunu

(18) [koira] ei halua kuunnella

(19) koira on purenut; anna nyt minä lukee

(20) antaa te pojalle sille taapas 'se antaa sille pojalle saappaan'

$7 \quad$ Käytän tässä termiä verbi (esim. Takkinen 2008; Liddell 2003). Jantunen (2010) käyttää termiä verbaali esitellessään suomalaisen viittomakielen pääsanaluokkia. 
Villen molemmat kielet olivat kehittyneet vuoden aikana. Verrattuna aikaisempaan suomen kielen taito on kohentunut suhteessa enemmän, mikä ilmeni pidentyneinä ilmauksina ja taivutuksen lisääntymisenä. Villellä oli ollut vanhempien arvion mukaan ikään nähden vahvahko viittomakielen taito ennen sisäkorvaistutteen asentamista. Sisäkorvaistutteen asentamisen jälkeen kotona on käytetty enemmän suomen kieltä. Viittomakieltä käytetään tilanteissa, joissa sisäkorvaistutetta ei ole tai se ei auta saamaan puheesta selvää. Villellä on sekä suomenkielisiä että viittomakielisiä kavereita ja viittomakielen kontakteja joissakin harrastuksissa. Ville on lisäksi kiinnostunut molemmista kielistä ja kokee tarvitsevansa molempia.

\subsection{Liisa: $2 ; 9$ ja $3 ; 9$}

Liisan kuurous diagnosoitiin neljän kuukauden iässä (taulukko 1). Perhe alkoi opetella viittomakieltä Liisan ollessa puolivuotias. Sisäkorvaistutteen hän sai ollessaan puolentoista vuoden ikäinen. Ensimmäinen aineisto kerättiin, kun Liisa oli 2;9 ja toinen, kun hän oli 3;9 vanha.

Hieman alle kolmevuotiaana, kun Liisa oli omaksunut viittomakieltä reilun kaksi vuotta, Liisa viittoi verrattain vähän. Aineistossa esiintyi vain erillisiä viittomia (ORAVA; MANSIKKA; LINTU; VUOHI) sekä viittoman ja osoituksen yhdistelmiä (PUPU os-kuva; ISÄ ÄITI PUPU (yhdessä puheen kanssa). Viittoma-artikulaatiossa oli iänmukaista kehittymättömyyttä, liikkeiden ja käsimuotojen yksinkertaistamista (vrt. liite 1). Liisa ymmärsi viittomista jonkin verran, mutta tarvitsi toistamista usein.

Liisa oli käyttänyt sisäkorvaistutetta runsaan vuoden ensimmäiseen aineiston keruuseen mennessä. Hän puhui hyvin vähän, 1-2-tavuisia sanoja (hala = kala; una = juna; os-kuva pieni ehmä = lehmä). Hän ymmärsi yksinkertaista puhetta kohtalaisen hyvin, mutta itse osoitteli usein kuvia tai viittoi vastaukseksi kysymyksiin. Artikulaatio oli vielä epäselvää, useita konsonantteja jäi pois tai korvautui toisella.

Hiukan alle nelivuotiaana Liisa viittoi vähän ja käytti erillisiä viittomia (ÄITI; KAKSI; VIHREÄ) yhdisti osoituksen ja viittoman (21) 
tai viittoi kahden viittoman ilmauksia, joskus pitempiäkin (22-29). Viittoma-artikulaatiossa liikkeet olivat hyvin pieniä, mikä teki artikulaatiosta vähän epäselvää. Käsimuodot olivat ikään nähden selviä. Liisa ei ollut oikein tottunut viittomakieliseen kommunikaatioon: hän ei aina katsonut viittojaa tämän viittoessa eikä aina ymmärtänyt aikuisen viittomista.

(21) os-kuva APINA; os-kuva HYPÄTÄ-korkealle

(22) LEPPÄKERTTU LENTÄÄ; PUPU MENNÄ os-kuva

(23) PUPU PUDOTA käsi suulle 'voi kauhistus'

(24) AUTO PÄÄLLÄ AUTO PÄÄLLÄ [seisoo]

(25) os-kuva MINÄ OMA-1 ISÄ os-kuva 'tuossa on minun isä'

(26) EI MINÄ EI EI-TIETÄÄ

(27) KÄVELLÄ ISTUA PUPU KAATUA

(28) os-kuva ISÄ os-kuva LAPSET; ÄITI ISÄ MENNÄ

(29) os-kuva MAALATA os-kuva PAINAA-KÄMMEN-SEINÄÄN

Hieman alle nelivuotiaana, käytettyään sisäkorvaistutetta reilun kaksi vuotta, Liisa ymmärsi puhuttua suomea hyvin ja tuotti itse pitkiä ilmauksia, joissa oli sekä pää- että sivulauseita (31-32). Hän käytti monipuolista sanastoa (32-33). Käyttöön oli tullut sijataivutusta (myös rektiossa) (34-35) samoin kuin verbitaivutusta (36). Myös artikulaatio oli suhteellisen selvää, joskus sanoissa oli konsonanttipuutoksia (tuu'u = tullu). Äänteet Liisa osasi tuottaa muuten paitsi /r/ ääntyi vielä joskus /l/-äänteenä. Liisa tunsi jo aakkosetkin ja osasi sanoa ne suomeksi ja sormittaa.

(30) Hiiet y'ittää tuu’a Tu Tupu Tupunan päälle

(31) Se [joulupukki] tuli sinne sinne ku mä menin sit sinne X-mummin ja Y-ukin luokse ni sitte se tuli

(32) Tässä se olava heittelee käpyjä, kilistää sitä kelloa

(33) Mullaki on kukkahattu

(34) Ja poika pitää Tupu Tupunaa sylissä

(35) Tupu Tupuna latsastaa hevosella

(36) juoksee... antamaa jollekin lahjaa; tämä ei nuku

Liisan suomen kielen taidot olivat kehittyneet vuoden aikana huomattavasti, sen sijaan viittomakielen taidot eivät mainittavasti. Ennen 
sisäkorvaistutetta hän oli omaksunut jonkin verran viittomistoa, tuottanut lyhyitä ilmauksia ja pystynyt ilmaisemaan itseään viittomakielellä ikätasonsa mukaan. Istutteen jälkeen kotona oli käytetty aluksi rinnakkain puhuttua ja viitottua suomea, myöhemmin vain viittomia puheen tukena. Viittomakieltä käytetään tilanteissa, jossa Liisa ei kuule istutteellaan tai se ei ole paikoillaan. Sisäkorvaistutteesta on ollut hänelle huomattavasti hyötyä puhutun kielen omaksumisessa, mutta viittomakieli ei ollut kehittynyt iän mukaisesti sen käytön vähyyden vuoksi.

\subsection{Muiden lasten kehitys}

Kalle $(7 ; 6$ ja 8;6) oli ollut huonokuuloinen ennen sisäkorvaistutteen saamista ja oli siis omaksunut jo suomen kieltä korvantauskojeen avulla, mutta artikulaatio oli ollut epäselvää. Hän oli tarvinnut myös viittomien tukea ymmärtääkseen puhetta hyvin. Aineistosta kävi ilmi, että hän käytti viittoessaan lähinnä viitottua suomea ${ }^{8}$. Kallen viittomakielen taidot eivät olleet juuri kehittyneet vuoden aikana - hän myös itse koki, ettei osaa viittoa hyvin. Suomen kielen taidot sitä vastoin olivat parantuneet huomattavasti: hän käytti pitkiä, monisanaisia ilmaisuja, sanasto oli rikastunut ja sisälsi spesifejä termejä; myös verbikonstruktiot olivat monipuolistuneet. Hän oli muutenkin aktiivisempi keskustelija kuin vuotta aikaisemmin. Puolentoista vuoden istutteen käytön jälkeen myös konsonanttien ja konsonanttiyhtymien artikulaatio oli selvempi. Sisäkorvaistute oli siis selvästi edistänyt Kallen puheen omaksumista. Samalla kun suomen kielen taito parani ja Kalle alkoi tuntea pärjäävänsä sillä, tarve käyttää viittomakieltä ja sitä mukaa kiinnostuskin viittomakieleen väheni. Kotona käytettiin viitottua suomea vain tarvittaessa (silloin kun puheella ei eri syistä saatu asioita selväksi). Myös koulussa Kalle käytti yksinomaan suomen kieltä. Viittomakieli näytti menettäneen funktionsa Kallen elämässä.

$8 \quad$ Viitottu suomi (viitottu puhe) tarkoittaa, että viittomat tuotetaan usein puheen ohella samassa järjestyksessä kuin puheessa ilman viittomakielen kieliopillisia piirteitä. http://www.kuulokynnys.fi/kuulokynnys/kommunikaatio/kommunikaatiomenetelmat/viitottu puhe/ (9.8.2013). 
Jussi $(5 ; 9$ ja 6;9) sai sisäkorvaistutteen 1 1/2 vuoden iässä. Jussilla oli ollut vanhempien kertoman mukaan vahvahko viittomakielen taito ennen sisäkorvaistutteen asentamista, koska kotona oli viitottu hänen syntymästään asti ja vanhempi sisarus on käyttänyt viittomakieltä pääasiallisena kielenään. Sisäkorvaistutteen saamisen jälkeen $(1 ; 6)$ perheessä on käytetty molempia kieliä, usein viitottu ja puhuttu yhtä aikaa. Joissain tilanteissa on käytetty vain viittomakieltä, joissain vain suomen kieltä. Jussin viittomakielen taidot olivat kehittyneet vuoden aikana selvemmin kuin suomen kielen taidot, mikä ilmeni monipuolisina viittomakielisinä ilmauksina, joissa esiintyi kuvailevia viittomia, viittomien suuntaamista tilassa sekä ei-manuaalisia kieliopillisia keinoja. Hän myös ymmärsi toisen viittomista hyvin, ja vuorovaikutus oli sujuvaa. Suomen kielen ilmaisut olivat lyhyempiä, ja niissä esiintyi puutteita sekä verbien että nominien taivutuksessa samoin kuin artikulaatiossa. Hän tarvitsi visuaalisia vihjeitä ymmärtääkseen puhetta. Vanhempien mielestä Jussi nauttii viittomakielen käytöstä, joskin kaverit koulussa ja lähiympäristössä ovat suomenkielisiä.

Maija (4;6 ja 5;6) on ennen sisäkorvaistutteen asentamista vanhempien mukaan viittonut lauseita ja viittomistoa oli ollut jo runsaasti. Sisäkorvaistutteen saamisen jälkeen $(2 ; 10)$ kotona on käytetty enemmän suomea kuin viittomakieltä. Toinen vanhemmista puhuu yleensä, toinen viittoo enemmän, joskin usein puheen rinnalla. Tilanteissa, joissa kuuleminen on vaikeaa, käytetään vain viittomakieltä. Viittomakielisiä kontakteja Maijalla ei ole Juniori-ohjelman ulkopuolella. Aineistosta käy ilmi, että vuoden aikana viittomakielen taidot olivat kehittyneet enemmän kuin suomen kielen taidot. Maija viittoi moniviittomaisia ilmauksia, joissa oli alkavaa tilan käyttöä (verbien suuntaamista tilassa ja yksinkertaisia kuvailevia viittomia). Suomen kielen ilmaisut olivat 2-3-sanaisia, joissa esiintyi hyvin vähän nominien tai verbien taivutusta.

Matti $(3 ; 9$ ja 4;9) oli ennen sisäkorvaistutteen asentamista oppinut ilmaisemaan itseään yksittäisillä viittomilla ja lyhyillä viittomakielisillä ilmauksilla. Istutteen jälkeen (2;2) kotona on käytetty sekä puhuttua suomea että viitottua suomea, joissakin tilanteissa vain suomea, joissakin 
vain viittomista. Ympäristö on suomenkielinen, mutta Matti käyttää viittomakieltä Juniori-ohjelman kursseilla ja joskus tapaa viittovaa tuttavaa. Matin suomen kielen taidot olivat vuoden aikana kehittyneet yhden ja kahden sanan ilmaisuista kolmen ja useamman sana ilmauksiksi, joissa sijataivutus ja verbitaivutus olivat aluillaan. Puheesta sai paremmin selvää kuin vuotta aikaisemmin, mutta konsonanteissa ja konsonanttiyhtymissä esiintyi puutteita. Matin viittomakielen taidot eivät juuri olleet parantuneet: hän viittoi yksittäisiä viittomia ja kahden viittoman ilmaisuja, joissa ei esiintynyt kieliopillisia keinoja.

\subsection{Tulosten koontia}

Edellä olen tarkastellut kahden lapsen suomalaisen viittomakielen ja suomen kielen aineistoa vuoden välein kerätyissä aineistoissa. Lisäksi olen kuvannut tiiviisti neljän muun lapsen aineistoissa havaittavissa olevia kielellisiä piirteitä. Taulukko 3 esittää tiivistäen, kuinka kunkin lapsen viittomakieli (SVK) ja suomen kieli kehittyivät vuoden aikana.

TAULUкко 3. Lasten viittomakielen ja suomen kielen kehitys vuoden aikana

\begin{tabular}{|l|l|l|l|l|l|l|}
\hline \multirow{2}{*}{ Kieli } & \multicolumn{7}{|c|}{ Kielten kehitys vuoden aikana } \\
\cline { 2 - 7 } & \multicolumn{1}{|c|}{ Kalle } & \multicolumn{1}{c|}{ Ville } & \multicolumn{1}{c|}{ Jussi } & \multicolumn{1}{c|}{ Maija } & \multicolumn{1}{c|}{ Matti } & \multicolumn{1}{c|}{ Liisa } \\
\hline SVK & hyvin vähän & selvästi & selvästi & selvästi & vähän & vähän \\
\hline suomi & $\begin{array}{l}\text { huomat- } \\
\text { tavasti }\end{array}$ & $\begin{array}{l}\text { huomat- } \\
\text { tavasti }\end{array}$ & $\begin{array}{l}\text { jonkin } \\
\text { verran }\end{array}$ & $\begin{array}{l}\text { jonkin } \\
\text { verran }\end{array}$ & $\begin{array}{l}\text { huomat- } \\
\text { tavasti }\end{array}$ & $\begin{array}{l}\text { huomat- } \\
\text { tavasti }\end{array}$ \\
\hline
\end{tabular}

Kallen suomen kieli kehittyi hyvin vuoden aikana, ja viittomakielen käyttö perheessä väheni entisestään. Myös Kalle itse koki pärjäävänsä suomen kielellä hyvin, ja hänen motivaationsa viittomakielen käyttöön väheni. Hänen kohdallaan voidaan puhua subtraktiivisesta kaksikielisyydestä, jossa toisen kielen käytön lisääntyessä toisen käyttö vähenee ja mahdollisesti loppuu kokonaan, mikä johtaa kielen attritioon.

Villellä on ollut vahvahko viittomakieli ennen puheen oppimista. Hänellä on myös viittomakielisiä kontakteja ja viittomakielen käyttöä 
arkipäivässä jonkin verran, vaikka se onkin vähentynyt sisäkorvaistutteen käytön myötä. Viittomakielen taito on vuoden aikana kehittynyt jonkin verran, mutta suomen kielen taito huomattavasti. Jussi taas on kiinnostunut enemmän viittomakielestä. Hän on käyttänyt sitä pienestä pitäen. Hänen suomen kielensä on kyllä kehittynyt jonkin verran kieliopillisesti, mutta sitä saattavat hidastaa kuulemisen vaikeudet, koska hän tarvitsee paljon visuaalista informaatiota kuulemisen tueksi. Viittomakielellä on siis tärkeä sija tämän lapsen elämässä.

Maijan kielellinen kehitys ei ollut kovin nopeaa kummassakaan kielessä. Perhe on panostanut voimakkaasti puheeseen, mutta se ei ole kehittynyt odotusten mukaisesti. Asioita lapselle selitettäessä on käytetty myös viittomakieltä tai viitottua suomea varmistamaan, että lapsi ymmärtää, mitä sanotaan. Viittomakielisiä kontakteja ei ole perhekurssin ulkopuolella, joten monipuolinen viittomakielen syötös on niukkaa.

Matti ja Liisa ovat saaneet sisäkorvaistutteen varhain, Liisa puolentoista ja Matti noin kahden vuoden iässä. Heidän suomen kielensä oli vuoden aikana kehittynyt huomattavasti, mutta viittomakielen taito vain hieman. He ymmärsivät toisten viittomista kohtalaisesti, mutta oma tuottaminen oli vaatimatonta. Perheet ovat panostaneet suomen kieleen paljon, ja lapset kokivat selviävänsä suomen kielellä melko hyvin. Vanhemmat itse viittovat enemmän lapsille, erityisesti silloin, kun istutetta ei ole tai sen kautta viesti ei saavuta lapsia. Liisalla oli muita kontakteja viittomakielisiin ainoastaan perhekurssilla ja Matillakin hyvin harvoin, joten monipuolinen viittomakielen syötös ja käyttö jäivät vähäiseksi.

Vanhempien haastatteluista ilmeni, etteivät kuulonhuollon edustajat ole kannustaneet perheitä viittomakielen käyttöön. He päinvastoin ovat varoittaneet viittomakielen negatiivisesta vaikutuksesta puheen kehitykseen. Tämä vaikuttaa siihen, että vanhemmat panostavat kovasti puheen kehitykseen. Vanhemmat toisaalta halusivat säilyttää viittomakielen toisena kielenä lapsellaan, mutta he eivät olleet saaneet rohkaisua ja riittävästi tietoa panostaakseen voimakkaasti myös viittomakieleen. 


\section{Pohdinta}

Tuloksista käy ilmi, että vuoden aikana suomen kieli oli parantunut selvästi neljällä lapsella ja kahdella lapsella jonkin verran. Viittomakieli oli kehittynyt kolmella lapsella, joista yhdellä myös suomen kieli oli kehittynyt hyvin, kahdella jonkin verran (taulukko 3). Lapset omaksuivat kieliä hyvin eri tavalla (ks. myös Duchesne ym. 2009; Szagun 2001; Huttunen \& Välimaa 2010), mikä johtui monista seikoista. Sen tähden jokaisen lapsen kielellinen kehitys on käsiteltävä yksilöllisesti.

Tässä tutkimuksessa nousee esiin asioita, joita on syytä miettiä kielivalintoja pohdittaessa. Kuulovamman diagnosointi-ikä on kielenkehityksen kannalta merkityksellinen. Varhainen kuulovamman havaitseminen auttaa perheitä orientoitumaan kommunikointiin visuaalisen kanavan kautta jo varhain. Varhaiseen diagnosointiin liittyy myös ikä, jolloin lapsen kanssa aletaan käyttää viittomakieltä. Optimaalista on valita viittomakieli varhaiseksi kieleksi, koska näön avulla lapsi voi omaksua kieltä, vaikka kuulo ei vielä avaisikaan pääsyä kieleen (ks. myös Takkinen 2003; Nelfelt \& Nordqvist 2004; Kushalnagar ym. 2010; Cramér-Wolrath 2013; tulossa).

Viittomakielen taito ennen sisäkorvaistutteen käyttöä näyttäisi olevan merkityksellinen myös puhutun kielen oppimiselle. Kaikki tutkimuksen lapsen ovat omaksuneet ensimmäisenä viittomakieltä ja osanneet kommunikoida sillä ennen sisäkorvaistutteen asentamista ja puheen oppimista. Tämän tutkimuksen nuorimpien lasten kuurous oli havaittu varhain, ja myös viittomakielen käyttö oli aloitettu varhain. Siinä vaiheessa, kun he saivat sisäkorvaistutteen, he ymmärsivät viittomakieltä ja tuottivat itsekin jo lyhyitä, parin viittoman ilmauksia. Vähitellen kun kuulo harjaantui puhutun kielen havaitsemiseen, he alkoivat pian tuottaa puheessaan samoja sanoja ja pikku lauseita, joita olivat jo viittomakielellä oppineet (vrt. Cramér-Wolrath 2013; tulossa). Kuitenkin on muistettava, että lapset hyötyvät sisäkorvaistutteesta yksilöllisesti (esim. Svirsky ym. 2000; Szagun 2001; Lonka \& Hasan 2006; Duchesne ym. 2009; Välimaa, Kunnari ja Jokela 2010; Huttunen ja Välimaa 2010). 
Suotuisaan tulokseen ovat osallisina ympäristötekijöiden lisäksi useat, niin fysiologiset kuin psykologisetkin tekijät. Myös yksilöllinen kiinnostus kieliin vaikuttaa tunnetusti siihen, kuinka kukin jaksaa paneutua erilaisten kielellisten resurssiensa kehittämiseen ja käyttöön.

Jos halutaan, että lapsi saavuttaa mahdollisimman toimivan kaksikielisyyden puhutussa ja viitotussa kielessä, on kielen syötöksen määrä ja laatu tärkeä. Kehittyäkseen kielet tarvitsevat monipuolista ja runsasta syötöstä sekä käyttöä erilaisissa tilanteissa (Hassinen 2005; Baker 2006; De Houwer 2009). Kodin ja lähiympäristön sekä yhteiskunnan ja lapsen kanssa tekemisissä olevien tahojen asenne viittomakielen ja puhutun kielen kaksikielisyyteen on erittäin merkittävä asia. Se on yhtä tärkeä niin kahta puhuttua (De Houwer 2009; Grosjean 2010) kuin kahta viitottuakin kieltä omaksuttaessa (Kushalnagar ym. 2010). Vähemmistökielen omaksuminen ja käyttö vaativat paljon tukea ja rohkaisua sekä lähiympäristöltä että yhteiskunnalta (Mueller Gathercole \& Thomas 2009; Hornberger 2009). Prestiisikielten oppimista ja käyttöä yhteiskunnassa tuetaan, mutta vähemmistökielet jäävät usein taloudellisista ja asenteellisista syistä sekä niiden yhteiskunnallista ja yksilöllistä merkitystä koskevan ymmärryksen puutteesta taka-alalle (Grosjean 2010; Hornberger 2009).

Tässä artikkelissa käsittelin vain yhden vuoden jaksoa kyseisten lasten kielten kehityksestä, mikä antaa ainoastaan kapean välähdyksen kielten omaksumisesta ja toiminnasta lasten elämässä. On tärkeää ja mielenkiintoista seurata, mitä kielten kehityksessä ja käytössä tapahtuu lasten kasvaessa ja kehittyessä kognitiivisesti, psyykkisesti sekä sosiaalisesti. Myös sisäkorvaistutteen lopullinen hyöty puhutun kielen omaksumisen kannalta tulee näkyviin vasta useiden vuosien käytön jälkeen (mm. Huttunen \& Välimaa 2010). Näistä syistä on tärkeää jatkaa kielten kehityksen ja käytön seuraamista.

Tämä yhden vuoden ajan seuranta osoittaa, että viittomakieli ei suinkaan haittaa puhutun kielen kehittymistä vaan pikemminkin tukee sitä. Kuuroille lapsille rakentuu viittomakielen kautta käsitys kielestä, sen funktiosta ja käytöstä. Tälle perustalle he pystyvät rakentamaan uutta 
kieltä, eikä heidän kielenkehityksensä ala vasta siitä, kun puhekielen omaksuminen sen mahdollistaisi (vrt. Cramér-Wolrath 2013; tulossa). Myös kuulevien vanhempien kuuleville vauvoille käyttämät viittomat näyttävät edistävän lasten puhekielen sanaston oppimista (Goodwyn ym. 2000). Jos puhuttu kieli ei kehity suotuisasti huolimatta siitä, että lapsi saa auditiivista harjaannusta, siihen voi olla muita syitä, esimerkiksi laitteen säätöjen ongelma, kielellinen erityisvaikeus tai neurologinen ongelma (vrt. Wiley ym. 2005; Edwards 2007; Huttunen \& Välimaa 2010). Tällöin viittomakielen merkitys lapsen kielelliselle kehitykselle entisestään korostuu. Pisonin ja tutkijakumppaneiden (2008) mukaan tietyt biologiset tekijät ja kognitiivisiin prosesseihin liittyvät häiriöt vaikuttavat siihen, kuinka kukin lapsi hyötyy sisäkorvaistutteesta. He korostavat, että tältä alueelta tarvittaisiin enemmän tutkimusta, jotta voitaisiin panostaa oikeanlaiseen kielen kehityksen tukemiseen. Toisaalta kaksikielisyystutkimukset osoittavat, että tähdättäessä kaksikielisyyteen, molempien kielien omaksumista täytyy tukea sekä positiivisen asenteen että taloudellisten resurssien kautta.

Jos perheissä pyritään puhutun kielen ja viittomakielen kaksikielisyyteen, perheitä on tuettava tässä pyrkimyksessä (vrt. Mueller Gathercole \& Thomas 2009). Grosjeanin (2010) mukaan ratkaisevaa kaksikieliseksi kehittymisessä on se, että tietävät ja välittävät aikuiset helpottavat lasten matkaa vaiheesta toiseen ja heidän kanssaan lapset voivat keskustella kokemuksistaan. Tällaisen tuen varassa kaksikielisyys ja -kulttuurisuus on mahdollista saavuttaa menestyksellisesti. Siksi molempien kielien käyttö ja opetus on turvattava mahdollisimman varhain kotona ja lähiympäristössä, ja myöhemmin koulussa on annettava opetusta molemmissa kielissä. 


\section{Kiitokset}

Juhana Saloselle viittomakielisen aineiston annotoinnista sekä aineistoon liittyvistä kommenteista ja keskusteluista.

\section{Lähteet}

Ahti, Helena 2000. Perheen ohjaus lapsen kuulovammadiagnoosin varmistuessa. - Eila Lonka, Anna-Maija Korpijaakko-Huuhka (Toim.). Kuulon ja kielen kuntoutus. Helsinki: Palmenia-kustannus, 127-142.

Baker, Collin 2001. Foundations of Bilingual Education and Bilingualism. Clevedon: Multilingual Matters.

Bialystok, Ellen 2010. Bilingualism. - WIREs Cognitive Science 1 (4), 559-572. http://dx.doi.org/10.1002/wcs.43

Chen Pichler, Deborah 2012. Language acquisition. - Ronald Pfau, Bencie Woll, Markus Steinbach (Eds.). Handbook of Linguistics and Communications Science: Sign Language. Berlin: de Gruyter, 647-686.

Cramér-Wolrath, Emelie 2013. Signs of Acquiring Bimodal Bilingualism Differently: A Longitudinal Case Study of Mediating a Deaf and Hard of Hearing Twin in a Deaf Family. Doctoral Thesis in Special Education. Stockholm: Stockholm University.

Cramér-Wolrath, Emelie (tulossa). Sequential bimodal bilingual acquisition: Mediation using a cochlear implant as a tool. - Hyväksytty julkaistavaksi lehdessä Deafness \& Education International.

De Houwer, Annick 2009. Bilingual First Language Acquisition. Bristol: Multilingual Matters.

Deuchar, Margaret, Suzanne Quay 1999. Language choice in the earliest utterances: A case study with methodological implications. - Journal of Child Language 26 (2), 461-475. http://dx.doi.org/10.1017/S0305000999003852

Duchesne, Louise, Ann Sutton, François Bergeron 2009. Language achievement in children who received cochlear implants between 1 and 2 years of age: Group trends and individual patterns. - Journal of Deaf Studies and Deaf Education 14 (4), 465-485. http://dx.doi.org/10.1093/deafed/enp010

Edwards, Lindsey 2007. Children with cochlear implants and complex needs: A review of outcome research and psychological practices. - Journal of Deaf Studies and Deaf Education 12 (3), 258-268. http://dx.doi.org/10.1093/ deafed/enm007 
Genesee, Fred, Elene Nicoladis 2006. Bilingual acquisition. - Erika Hoff, Marilyn Shatz (Eds.). Handbook of Language Development. Oxford: Blackwell, 324-342.

Goodwyn, Susan, Linda Acredolo, Atherine Brown 2000. Impact of symbolic gesturing on early language development. - Journal of Nonverbal Behaviour 24 (2), 81-103. http://dx.doi.org/10.1023/A:1006653828895

Grosjean, François 2010. Bilingual: Life and Reality. Cambridge: Harvard University Press.

Haapanen, Ulla-Maija, Tuija Wainio 2010. Suomalaisen viittomakielen verbaalityyppien 1 ja 2 alaluokittelua sekä huomioita glossauksesta. - Tommi Jantunen (Toim.). Näkökulmia viittomaan ja viittomistoon. Jyväskylä: Jyväskylän yliopisto, Soveltavan kielentutkimuksen keskus, 79-97.

Hakulinen, Auli 1997. Vuorottelujäsennys. - Liisa Tainio (Toim.). Keskusteluanalyysin perusteet. Tampere: Vastapaino, 32-55.

Hassinen, Sirje 2005. Lapsesta kasvaa kaksikielinen. Helsinki: Oy Fin Lectura AB. Heller, Monica 2007. Bilingualism as ideology and practice. - Monica Heller (Ed.). Bilingualism: A Social Approach. Basingstoke: Palgrave, 1-22.

Hornberger, Nancy 2009. Multilingual education policy and practice: Ten certainties (grounded in indigenous experience). - Language Teaching 42 (2),197-211. http://dx.doi.org/10.1017/S0261444808005491

Huttunen, Kerttu, Taina Välimaa 2010. Parents' views on changes in their child's communication and linguistic and socioemotional development after cochlear implantation. - Journal of Deaf Studies and Deaf Education 15 (4), 383-404. http://dx.doi.org/10.1093/deafed/enq029

Jantunen, Tommi 2008. Fixed or free: Order of the verbal predicate and its core arguments in declarative transitive clauses in Finnish Sign Language. SKY Journal of Linguistics 21, 83-123.

Jantunen, Tommi 2009. Tavu ja lause: tutkimuksia kahden sekventiaalisen perusyksikön olemuksesta suomalaisessa viittomakielessä. Jyväskylä: Jyväskylän yliopisto.

Jantunen, Tommi 2010. Suomalaisen viittomakielen pääsanaluokat. - Tommi Jantunen (Toim.). Näkökulmia viittomaan ja viittomistoon. Jyväskylä: Jyväskylän yliopisto, Soveltavan kielentutkimuksen keskus, 59-78.

Kotti, Voitto 2002. Kuulokeskuksen näkökulma kuntoutusjärjestelmään. - Eeva Lehto, Marja Hasan, Ritva Parkas (Toim.). Satakieliseminaari 2002. Helsinki: Satakieliprojekti, 55-58.

Kushalnagar, Poorna, Gaurav Mathur, Christopher Moreland, Donna Jo Napoli, Wendy Osterling, Carol Padden, Christian Rathmann 2010. Infants and 
children with hearing loss need early language access. - The Journal of Clinical Ethics 21 (2), 143-54.

Liddell, Scott 2003. Grammar, Gesture, and Meaning in ASL. Cambridge: Cambridge University Press. http://dx.doi.org/10.1017/CBO9780511615054

Lonka, Eila, Marja Hasan 2006. Sisäkorvaistutetta käyttävien lasten kommunikaatio-, koulu- ja päivähoitotilanne Suomessa. - Eeva Lehto, Marja Hasan, Ritva Parkas (Toim.). Satakieliseminaari 2006. Helsinki: Satakieliprojekti, 73-79.

Meisel, Jürgen 2004. The bilingual child. - Tej Bhatia, William Ritchie (Eds.). The Handbook of Bilingualism. Malden, MA: Blackwell, 91-113.

Mueller Gathercole, Virginia, Enlli Môn Thomas 2009. Bilingual first language development: Dominant language takeover, threatened minority language take-up. - Bilingualism: Language and Cognition 12 (2), 213-237. http:// dx.doi.org/10.1017/S1366728909004015

Mäntylä, Katja, Sari Pietikäinen, Hannele Dufva 2009. Kieliä kellon ympäri: perhe monikielisyyden tutkimuksen kohteena. - Puhe ja kieli 29 (1), 27-37.

Nelfelt, Karin, Åsa Nordqvist 2004. “DET HÖRS” - Från visuell till auditiv kommunikation hos små döva barn med cochleaimplantat. Gothenburg Papers in Theorethical Linguistics 31. Göteborg: Univ., Lingvistiska inst.

Padden, Carol A. 2008. Foreword. - Carolina Plaza-Pust, Esperanza MoralesLópez (Eds.). Sign Bilingualism: Language Development, Interaction, and Maintenance in Sign Language Contact Situations. Studies in Bilingualism, 38. Philadelphia: Benjamins, xi-xiv.

Petitto, Laura Ann, Marina Katerelos, Bronna Levy, Kristine Gauna, Karine Tetreault, Vittoria Ferraro 2001. Bilingual signed and spoken language acquisition from birth: Implications for the mechanism underlying early bilingual language acquisition. - Journal of Child Language 28 (2), 453496. http://dx.doi.org/10.1017/S0305000901004718

Pfau, Roland, Josep Quer 2010. Nonmanuals: Their grammatical and prosodic roles. - Diane Brentari (Ed.). Sign Languages. Cambridge: Cambridge University Press, 381-402.

Pietikäinen, Sari, Hannele Dufva, Katja Mäntylä 2010. Monikielisyys liikkeessä: monikielisen perheen kielelliset resurssit. - Mikael Garant, Mirja Kinnunen (Toim.). AFinLA-e Soveltavan kielitieteen tutkimuksia 2, 17-30.

Pisoni, David, Christopher Conway, William Kronenberger, David Horn, Jennifer Karpicke, Shirley Henning 2008. Efficacy and effectiveness of cochlear implants in deaf children. - M. Marschark (Ed.). Deaf Cognition: 
Foundations and Outcomes. Australia \& New Zealand: Oxford University Press, 52-101.

Rainò, Päivi 2001. Mouthings and mouth gestures in Finnish Sign Language (FinSL). - Penny Boyes-Braem (Ed.). The Hands are the Head of the Mouth. Hamburg: Signum, 41-49.

Rissanen, Terhi 1985. Viittomakielen perusrakenne. Helsingin yliopiston yleisen kielitieteen laitoksen julkaisuja 12. Helsinki: Helsingin yliopisto.

Rissanen, Terhi 2000. Suomalaisen viittomakielen lauseoppia. - Anja Malm (Toim.). Viittomakieliset Suomessa. Helsinki: Finn Lectura, 147-167.

Svirsky, Mario, Amy Robbins, Karen Iler Kirk, David Pisoni, Richard Miyamoto 2000. Language development in profoundly deaf children with cochlear implants. - Psychological Science 11 (2), 153-158. http://dx.doi. org/10.1111/1467-9280.00231

Szagun, Gisela 2001. Language acquisition in young German-speaking children with cochlear implants: Individual differences and implications for conceptions of a 'sensitive phase'. - Audiology \& Neurotology 6, 288-297. http://dx.doi.org/10.1159/000046134

Takkinen, Ritva 2002. Käsimuotojen salat. Viittomakielisten lasten käsimuotojen omaksuminen 2-7 vuoden iässä. Helsinki: Kuurojen Liitto ry.

Takkinen, Ritva 2003. Viittomakielen omaksuminen äidinkielisessä ja kuulevassa viittomakieltä käyttävässä ympäristössä. - Puhe ja kieli 23 (3), 151-164.

Takkinen, Ritva 2008. Kuvailevat verbit suomalaisessa viittomakielessä. - Puhe ja kieli 28 (1), 17-40.

Takkinen, Ritva 2010. Kuvailevien viittomien leksikaalinen ja morfologis-gesturaalinen kuvaus: kielenopetuksen näkökulma. - Tommi Jantunen (Toim.). Näkökulmia viittomaan ja viittomistoon. Jyväskylä: Jyväskylän yliopisto, Soveltavan kielentutkimuksen keskus, 99-113.

Tapio, Elina, Ritva Takkinen 2012. When one of your languages is not recognised as a language at all. - Jan Blommaert, Sirpa Leppänen, Päivi Pahta, Tiina Virkkula (Eds.). Dangerous Multilingualism. Hampshire: Palgrave Macmillan, 284-308.

Välimaa, Taina, Sari Kunnari, Henna Jokela 2010. Sisäkorvaistutetta käyttävien lasten morfosyntaktiset taidot: monitapaustutkimus. - Puhe ja kieli 30 (3), 157-169.

Wiley Susan, Martin Jahnke, Jareen Meinzen-Derr, Daniel Choo 2005. Perceived qualitative benefits of cochlear implants in children with multi-handicaps. - International Journal of Pediatric Otorhinolaryngology 69 (6), 791-798. http://dx.doi.org/10.1016/j.ijporl.2005.01.011 
Yip, Virginia, Stephen Matthews 2007. The Bilingual Child: Early Development and Language Contact. Cambridge: Cambridge University Press. http:// dx.doi.org/10.1017/CBO9780511620744

\section{Verkkolähteet}

ELAN-ohjelma. http://tla.mpi.nl/tools/tla-tools/elan/ (9.8.2013).

Transana-ohjelma. http://www.transana.org/ (9.8.2013).

Juniori-ohjelma. http://www.kuurojenpalvelusaatio.fi/fin/apua arkeen/junioriohjelma/ (9.8.2013).

Kuuloliitto. http://www.kuuloliitto.fi/fin/kuulo/sisakorvaistute/rakenne/ (9.8.2013).

Viitottu puhe. http://www.kuulokynnys.fi/kuulokynnys/kommunikaatio/kommunikaatiomenetelmat/viitottu puhe/ (9.8.2013).

\section{Ritva Takkinen}

Jyväskylän yliopisto, kielten laitos (F), suomalainen viittomakieli

PL 35

40014 Jyväskylän yliopisto, Finland

ritva.takkinen@jyu.fi 


\section{Liite 1. Tiivistelmä suomalaisen viittomakielen kehityskulusta $1 \frac{1}{2}$ ja 5 1⁄2 vuoden välillä}

Huom. Vahvennettua tekstiä on käytetty silloin, kun kehityspiirre esiintyi sekä äidinkielisessä että ei-äidinkielisessä ympäristössä elävillä lapsilla. Normaalia tekstiä on käytetty, kun piirre esiintyi vain äidinkielisessä ympäristössä elävillä lapsilla.

\begin{tabular}{|c|c|c|}
\hline $\mathscr{9}$ & Viittomiston kehitys & Foneettis-fonologinen kehitys \\
\hline 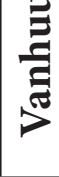 & $\begin{array}{l}\text { Äidinkieliset ja ei-äidinkieliset } \\
\text { lapset } \\
\text { Äidinikieliset lapset }\end{array}$ & $\begin{array}{l}\text { Äidinkieliset ja ei-äidinkieliset } \\
\text { lapset } \\
\text { Äidinikieliset lapset }\end{array}$ \\
\hline $\begin{array}{c}1 \\
1 / 2\end{array}$ & - substantiivejä, verbejä & $\begin{array}{l}\text { - yksinkertaisia käsimuotoja ja } \\
\text { liikkeitä }\end{array}$ \\
\hline 2 & $\begin{array}{l}\text { - substantiivejä, verbejä, } \\
\text { adjektiivejä, pronnominaalisia } \\
\text { osoituksia, numeraaleja, } \\
\text { adverbejä } \\
\text { - kieltojohdoksia }\end{array}$ & $\begin{array}{l}\text { - variaatioita } \\
\text { käsimuodoissa, liikkeissä, } \\
\text { käsimuodonmuutoksissa ja } \\
\text { orientation muutoksissa } \\
\text { - vaikeuksia tuottaa kahden } \\
\text { käden viittomia }\end{array}$ \\
\hline 3 & $\begin{array}{l}\text { - substantiivejä, verbejä, } \\
\text { adjektiivejä, pronnominaalisia } \\
\text { osoituksia, numeraaleja, } \\
\text { adverbejä, muita } \\
\text { - kieltojohdoksia } \\
\text { - värikäsite } \\
\text { - numerokäsite } \\
\text { - ajankäsite }\end{array}$ & $\begin{array}{l}\text { - variaatioita käsimuodoissa, } \\
\text { - vaikeutta tuottaa käsimuodon } \\
\text { ja orientaation muutoksia } \\
\text { - vaikeutta proksimaalisen } \\
\text { ja distaaalisen liikkeen } \\
\text { yhdistämisessä } \\
\text { - vaikeutta kaksikätisten } \\
\text { viittomien tuottamisessa }\end{array}$ \\
\hline 4 & $\begin{array}{l}\text { - abstrakteja viittomia } \\
\text { - yläkäsitteitä } \\
\text { - yhdysviittomia } \\
\text { - kieltojohdoksia } \\
\text { - luku- ja aikakäsite laajentunut } \\
\text { edellisestä }\end{array}$ & $\begin{array}{l}\text { - joissakin käsimuodoissa vielä } \\
\text { variaatioita } \\
\text { - jonkin verran vaikeuksia } \\
\text { proksimaalsien ja distaalisen } \\
\text { liikkeen yhdistämisessä } \\
\text { - jonkin verran vielä vaikeuksia } \\
\text { kaksikätisissä viittomissa }\end{array}$ \\
\hline 5 & $\begin{array}{l}\text { - viittomavarasto monipuolistunut } \\
\text { - abstrakteja viittomia lisää }\end{array}$ & $\begin{array}{l}\text { - perusparametrit hallinnassa } \\
\text { - idiolektista variaatiota }\end{array}$ \\
\hline
\end{tabular}




\begin{tabular}{|c|c|c|}
\hline $\boldsymbol{g}$ & Morfologinen kehitys & Syntaktinen kehitys \\
\hline |ב & $\begin{array}{l}\text { Äidinkieliset ja ei-äidinkieliset } \\
\text { lapset } \\
\text { Äidinikieliset lapset }\end{array}$ & $\begin{array}{l}\text { Äidinkieliset ja ei-äidin- } \\
\text { kieliset lapset } \\
\text { Äidinikieliset lapset }\end{array}$ \\
\hline $\begin{array}{c}1 \\
1 / 2\end{array}$ & & $\begin{array}{l}\text { - yhden viittoman ilmauksia } \\
\text { - viittoman ja osoituksen } \\
\text { yhdistäminen } \\
\text { - kahden viittoman yhdis- } \\
\text { täminen }\end{array}$ \\
\hline 2 & $\begin{array}{l}\text { - ensimmäisiä taivutuksen merkkejä } \\
\text { ilmaantuu }\end{array}$ & $\begin{array}{l}\text { - kahden viittoman ilmaisuja } \\
\text { signs } \\
\text { - 3-4 viittoman ilmauksia } \\
\text { - myöntö- ja kieltoilmauksia }\end{array}$ \\
\hline 3 & $\begin{array}{l}\text { - yhdysviittomia } \\
\text { - negation nonmanuaalista ilmaisua } \\
\text { - omistusmuotoja } \\
\text { - yksinkertaisia monikon muotoja } \\
\text { - numeraalijohdoksia } \\
\text { - verbien ja adjektiivien adverbiaalista } \\
\text { modifiointia } \\
\text { - osoittavia verbejä (tilassa suuntautu- } \\
\text { via) } \\
\text { - kuvailevia verbejä }\end{array}$ & $\begin{array}{l}\text { - 3-4 viittoman ilmaisuja } \\
\text { - 5-6 viittoman ilmaisuja } \\
\text { - myöntö- ja kieltoilmauksia, } \\
\text { kysyviä ilmauksia } \\
\text { - viittomajärjestys vaihtelee } \\
\text { - ilmauksen muodostuksessa } \\
\text { kieliopillista tilankäyttöä }\end{array}$ \\
\hline 4 & $\begin{array}{l}\text { - } \text { yhdysviittomia } \\
\text { - omistusmuotoja } \\
\text { - numeraalijohdokset monipuolis- } \\
\text { tuneet } \\
\text { - monikon ilmaisut monipuolistuneet } \\
\text { - duali-ilmauksia kuvailevien verbien } \\
\text { avulla } \\
\text { - adjektiivien ja verbien adverbiaalista } \\
\text { modifiointia } \\
\text { - osoittavia verbejä (tilassa suuntautu- } \\
\text { via) } \\
\text { - kuvailevien verbien käyttö monipuoli- } \\
\text { sempaa (kuvailevia verbejä ilmaantuu } \\
\text { ei-äidinkielisessä ymp. elävillä lapsilla) }\end{array}$ & $\begin{array}{l}\text { - 5-6 viittoman ilmauksia } \\
\text { - pitkiä ja monipuolisia } \\
\text { ilmauksia } \\
\text { - kielto- ja myöntö- ja } \\
\text { kysymysilmauksia, käsky- } \\
\text { ilmauksia } \\
\text { - viittomajärjestys vaihtelee } \\
\text { - ilmauksen muodostuksessa } \\
\text { kieliopillista tilankäyttöä } \\
\text { (alkaa ei-äidinkielisesä } \\
\text { ympäristössä elävillä lapsilla) }\end{array}$ \\
\hline
\end{tabular}




\begin{tabular}{|c|c|c|}
\hline 5 & $\begin{array}{l}\text { - numeraalijohdokset monipulois- } \\
\text { tuneet } \\
\text { - monikon ja duaalin muodot monipu- } \\
\text { olistuneet } \\
\text { - verbien ja adjektiivien adverbiaalista } \\
\text { modifiointia } \\
\text { - monipuolisempaa osoittavien ver- } \\
\text { bien käyttöä } \\
\text { - kuvailevien verbien käyttö monipu- } \\
\text { olisempaa }\end{array}$ & $\begin{array}{l}\text { - myöntö-, kielto-, kysymys- } \\
\text { ja käskyilmauksia } \\
\text { • viittomajärjestys vaihtelee } \\
\text { • ilmauksen muodostuksessa } \\
\text { kieliopillista tilankäyttöä } \\
\text { (äidinkielisessä ympäristössä } \\
\text { elävilla lapsilla monipuoli- } \\
\text { sempaa) }\end{array}$ \\
\hline
\end{tabular}




\title{
Acquisition of a signed and a spoken language in children using a cochlear implant
}

\author{
RITVA TAKKINEN \\ University of Jyväskylä
}

This research deals with bilingual development in Finnish Sign Language (FinSL) and Finnish in six deaf children using cochlear implant. These children were born to hearing parents who started to learn and use sign language with their children after the deafness was recognized.

The language data (FinSL and Finnish) was collected in 2005 and in 2006 by videotaping the interaction between the child and a deaf adult native signer, and between the child and a hearing adult native speaker of Finnish. The ages of the children at the beginning of the research varied from 2;9 to 7;6. Background information was received by interviewing parents. The topics analysed in both languages were vocabulary, the length of utterances, inflection of verbals and nominals, articulation, comprehension of adult's speech/signing, and interaction.

In one-year period the development of spoken Finnish has been positive for every child. Four of them showed considerable improvement in Finnish considering the ability to discuss in Finnish, length of utterances, grammatical development, and articulation. Two children have made some progress. Sign language skills have improved in three children and their interaction in sign language was smoother than earlier. They used longer expressions and more spatial grammatical means in their expressions. Three of the children did not show much improvement. The children have more input in Finnish during the day than in sign language. In addition, several matters influence the development of each language.

Keywords: Finnish Sign Language; bimodal bilingual language acquisition; cochlear implant 